\title{
The Effect of Projective Identification, Conflict Resolution Styles, and Gender Roles on Marital Satisfaction
}

\author{
Yansıtmalı Özdeşim, Toplumsal Cinsiyet Rolleri ve Çatışma Çözme \\ Biçiminin Evlilik Doyumuna Olan Etkisi
}

Ayten Zara1, Fatma Gokce Yucel2

${ }^{1}$ Doç. Dr., ${ }^{2}$ KIn. Psk., Istanbul Bilgi University, Department of Psychology, Istanbul

\section{SUMMARY}

Objective: The aim of this study was to investigate the contribution of projective identification, gender roles, conflict resolution styles on marital satisfaction. Method: The data was collected from 123 married people. The booklet of demographic information form, Marital Life Scale, Paulson Daily Living Inventory, Conflict Resolution Styles Scale, and Bem-Sex Role Inventory were used to collect the data. Results: Their ages ranged from 23 to 44 years with the mean age of 32.5 (SD = 7.6). There was a strong relationship between projective identification, conflict resolution styles and marital satisfaction. A series of 3-way ANOVA analysis indicated that feminine characteristics have a significant effect on marital satisfaction $\left(\mathrm{F}(1,115)=4.059, \mathrm{p}<.05, \mathrm{np}^{2}=.034\right)$ and subordination behaviors $(F(1,115)=18.068, p<.01$, $\left.n p^{2}=.136\right)$. The multiple regression analysis indicated that study variables can account for $52 \%$ of variance in marital satisfaction. Idealizing projective identification positively (Beta $=.49, \mathrm{t}[122]=6.47 ; \mathrm{p}<.001$ ), persecuting projective identification negatively related to marital satisfaction (Beta $=-.39, \mathrm{t}[122]=-5.35, \mathrm{p}<.001)$. Conclusion: The findings suggest that the length of a marriage, having a child, having more children and unresolved conflicts decrease marital satisfaction. Feminine characteristics such as being a caretaker and being sensitive to other's feelings and masculine characteristics such as acting like a leader and being dominant increase marital satisfaction. Using persecuting projective identification leads the couple to transfer their early childhood conflicts on each other which then results in marital distress.

Key Words: Projective Identification, Conflict Resolution, Gender Roles, Marital Satisfaction

\section{ÖZET}

Amaç: Bu çalışmanın amacı, yansıtmalı özdeşimin, toplumsal cinsiyet rollerinin ve çatışma çözme biçiminin evlilik doyumuna olan etkisini araştırmaktır. Yöntem: Veriler, kolaylık örnekleme yoluyla 123 evli kişiden toplanmıştır. Demografik Bilgi Formu, Evlilik Yaşam Ölçeği, Paulson Gündelik Yaşam Envanteri, Çatışma Çözüm Stilleri Ölçeği ve Bem Cinsiyet Rolü Envanteri kullanılarak katılımcılardan veri toplanmıştır. Bulgular: Katılımcıların yaşları 23 ile 44 yaş arasında değişmiş, ortalama yaş 32.5. olarak bulunmuştur (SD = 7.6). Korelasyon analizleri yansıtmalı özdeşim, çatışma çözme biçimleri ve evlilik doyumu arasında güçlü ilişki bulmuştur. 3-yollu ANOVA analizleri dişil özelliklerin evlilik doyumuna $\left(\mathrm{F}(1,115)=4.059, \mathrm{p}<.05, \mathrm{np}^{2}=.034\right)$ ve itaat etme davranışlarına $(F(1,115)=18.068, p<.01$, $\left.n p^{2}=.136\right)$ önemli etkisi olduğunu göstermiştir. Çoklu regresyon analizleri bütün değişkenlerin, evliliğe doyumunun \%52'sini açıkladığını bulmuştur. İdealize edici yansıtmalı özdeşimin evlilik memnuniyeti ile olumlu (Beta $=.49, \mathrm{t}[122]=6.47 ; \mathrm{p}<.001)$, yıkıcı yansıtmalı özdeşimin ise olumsuz ilişkisi bulunmuştur (Beta $=-.39$, $t[122]=-5.35, p<.001)$. Sonuç: Bulgular evlilik uzunluğunun, çocuk sahibi olmanın, fazla çocuğun ve çözümlenmeyen çatışmaların evlilik doyumunu azalttığını göstermiştir. Sorumluluklarını yerine getiren ve başkalarının duygularına duyarlı dişil ile; lider ve başat olma eril karakteristik özelliklerinin evlilik doyumunu artırdığı bulunmuştur. Çiftlerin yansıtmalı özdeşim yoluyla çocukluk dönemi çatışmalarının birbirlerine yansıtarak evlilik stresi yaşadıkları ortaya çıkmıştır.

Anahtar Sözcükler: Yansıtmalı Özdeşim, Çatışma Çözme, Toplumsal Cinsiyet Rolleri, Evlilik Doyumu 


\section{INTRODUCTION}

Nowadays, increasing divorce and domestic violence rates have led researchers to investigate the determinants of marital satisfaction. Marital satisfaction comprises complex relational dynamics and various determinants therefore, it is hard to explain marital satisfaction with a simple definition. Many studies have examined different predictors of marital satisfaction but studies of the underlying processes which contribute to marital discord have not been clearly identified. Understanding the underlying sources of conflict in a marriage is very important, because it helps practitioners to place the specifics of what couples fight about into perspective, at which point we can aid couples to change destructive marital patterns, frustration, tension and marital conflict.

Many studies emphasize the importance of the couple's unconscious identification process as a principal mediator of couple's marital satisfaction and even argue that the activation of projective identification process is one of the underlying sources of conflicts that distress couples $(1,2,3,4,5,6)$. Partners enter into an intimate relationship preexisting internal working models and perceptual tendencies. When a conflict arises with a partner, they may judge that partner based on global generalization or on biased perception from the past. Each couple's past relationships are reenacted in their own marital relationship. Marital conflict in that sense is viewed as the "re-creation of conflict" that couples had with their parents in the past $(7,8)$. Children are both consciously and unconsciously affected by their parents' marital relationship. The child encodes his early interactions as "schemas" which includes memories about self and the object. In adult life activation of the schemas is important in establishing and maintaining intimate relationship $(7,9)$. Two unconscious processes in couple interaction styles were of particular interest to this study: persecuting projective identification and idealizing projective identification. In persecuting projective identification, the person projects unwanted part of himself/herself to other partner in order to get rid of anxiety. In idealizing projective identification the person attributes good qualities to the partner in order to protect the partner from his/her unwanted part of self. In sum, destructiveness, jealousy, and hate are more obvious in persecuting projective position while love, empathy and constructiveness are more apparent in idealizing projective position. Some studies suggest that couples with fear, anxiety, power struggles, conflict and ambivalence are more likely to use persecuting projective identification, whereas couples who have a need for closeness, protection, tend to be self-sacrificing and dependent are more likely to use idealizing projective identification $(10,11,12)$.

This internal source of conflicts in marriage as a whole can be source of many unresolved conflicts. How these conflicts are managed will affect significantly the level of intimacy and support experienced within the relationship. It is claimed that the conflict resolution strategies of each spouse contribute greatly to the relationship, culminating in satisfying marriage or its ending in divorce $(6,13,14,15)$. Each partner will bring into the marriage predispositions to manage conflict in certain ways based on their own family of origin experiences.

The resolution of conflict requires each partner to balance self-interest with a concern for the wellbeing of the other as well as the couple to reach a consensus regarding the importance of compromise and cooperation. Effective conflict resolution strategies enable couples to communicate in ways that promote understanding, resolve differences, and foster intimacy. Especially, accepting responsibility, complying with the other partner's wishes, and working together to create problem solving alternatives and applying them were found to be important factors in increasing couple relationship satisfaction $(16,17,18,19)$.

The important point here is that the conflict resolution strategies that evolve are quite variable and are influenced, in part, by the differences in role expectations in values, behaviors, powers, or resources in which one partner seeks to achieve his or her goals at the expense of the other. Men and women have different roles for example in the household division of labour, in parenting styles and responsibilities, in the expression of sexual intimacy and in psychological orientation. As a result 
of these differences, each spouse most likely derives different benefits, perceive different costs and evaluate the advantages of marriage differently. These differences in role expectations can the potential for role conflict in a marriage because each spouse's individual identity is closely tied to his or her role expectations. Indeed, a growing body of research indicated that men who owned modern roles have higher marital adjustment than men who owned traditional roles $(20,21,22)$, people with androgen roles have higher marital satisfaction than people with undifferentiated gender roles (23), women who own undifferentiated gender roles have lower marital satisfaction (24), couples who have gender stereotyped roles have higher relationship satisfaction score than couples who have non-stereotyped roles (25), and that high level of femininity in women and high level of masculinity in men increases the marital quality (18).

The study proposed that internal processes of intra-psychic personality, the conflict resolution and the gender roles are important dimensions in the understanding of couple marital satisfaction. Therefore, the main aim of this study was to investigate the contribution of projective identification, gender roles, and conflict resolution styles to marital satisfaction. The determinants of marital satisfaction may vary depending on the social, cultural and economic circumstances of a population. It was therefore crucial to conduct this study with married Turkish couples that differ culturally, socially and economically from other couples from different cultures. The result of this study will provide important data to understand the relational dynamics of Turkish couples which can be useful for both practical and academic use.

\section{METHOD}

\section{Participants}

One hundred and twenty three people participated in the present study; 54 of them were male and 69 of them were female. They were selected by convenience sampling. The participants were married people and their ages ranged between 23 and 44 with the mean age of 32.5. The length of marriage varied from one month to 18 years (see Table 1 ).
The participants came from different occupations such as lawyer, security guard, teacher, driver, airline hostess, psychologist, bank employee, engineer, hairdresser, lecturer and manager. The use of 16-itemised demographic information form gathered data in terms of marital, educational, economic status of the study participants as can be seen in Table 1.

Table1. Socio-Demographic Characteristics of the Participants

\begin{tabular}{|c|c|c|}
\hline & $\mathrm{N}$ & $\%$ \\
\hline \multicolumn{3}{|l|}{$\overline{\text { Sex }}$} \\
\hline Women & 69 & 56.1 \\
\hline Men & 54 & 43.9 \\
\hline Mean Age (SD) & \multicolumn{2}{|c|}{$32.5(7.6)$} \\
\hline \multicolumn{3}{|l|}{ Education } \\
\hline Primary & 10 & 8.1 \\
\hline Middle School & 5 & 4.1 \\
\hline High School & 20 & 16.3 \\
\hline University & 60 & 48.8 \\
\hline Master Degree & 24 & 19.5 \\
\hline Doctorate Degree & 3 & 2.4 \\
\hline Missing & 1 & .8 \\
\hline \multicolumn{3}{|l|}{ Living } \\
\hline Village & 6 & 4.9 \\
\hline Town & 23 & 4.9 \\
\hline City & 3 & 18.7 \\
\hline \multirow{2}{*}{ Metropolis } & 91 & 2.4 \\
\hline & & 74.0 \\
\hline \multicolumn{3}{|l|}{ Work } \\
\hline Yes & 116 & 94.3 \\
\hline No & 7 & 5.7 \\
\hline \multicolumn{3}{|l|}{ Meeting } \\
\hline School & 46 & 37.4 \\
\hline Friend & 47 & 38.2 \\
\hline Family & 17 & 13.8 \\
\hline Entertainment Places & 1 & .8 \\
\hline Electronic & 5 & 4.1 \\
\hline Others & 7 & 5.7 \\
\hline Mean duration of Marriage (SD) & \multicolumn{2}{|c|}{$5.7(5.2)$} \\
\hline \multicolumn{3}{|l|}{ Number of child } \\
\hline 0 & 65 & 52.4 \\
\hline 1 & 32 & 25.8 \\
\hline 2 & 20 & 16.1 \\
\hline 3 & 3 & 2.4 \\
\hline 4 & 1 & .8 \\
\hline Missing & 2 & 1.6 \\
\hline \multicolumn{3}{|l|}{ Income } \\
\hline 550-1500 TL & 11 & 8.9 \\
\hline $1501-3000 \mathrm{TL}$ & 23 & 18.7 \\
\hline $3001-5000 \mathrm{TL}$ & 38 & 30.9 \\
\hline 5001 - above & 51 & 41.5 \\
\hline
\end{tabular}




\section{Measures}

The Marital Life Scale (MLS) (26) measures an individual's marital satisfaction level. This scale examines how partners feel and what they think about their marital life. The MLS consists of ten questions, which are scored on a Likert scale from 1 to 5 . The reliability and validity of this scale was high. Test-retest reliability of MLS was found to be .85. Its internal-consistency was .91 for the pilot study group and .89 for the study group. Lastly, Cronbach's alpha in the present study for this scale was calculated at 89 .

Paulson Daily Living Inventory (PDLI) (27) examines the projective identification process in intimate relationship. The PDLI was translated into Turkish by Göral-Alkan and has 60 items, which are evaluated as true or false (10). The PDLI items were defined in two categories: persecuting projective identification, which consist of a total score of Persecuting Mother to Infant and Infant to Persecuting Mother subscales, and idealizing projective identification, which consist of the total score of Ideal Mother to Infant and Infant to Ideal Mother subscales. The PDLI's internal consistency was found to be .72 , the test-retest reliability was .78 and inter-rater reliability was .86 .

The Conflict Resolution Styles Scale (CRSS) (28) measures how people cope with their conflicts in close relationships. It consists of four subscales: positive conflict resolution style, negative conflict resolution style, subordination, and retreat. It is composed of 25 items and is a 6 point likert scale; varying from 1 "totally disagree" to 6 "totally agree." The positive conflict resolution subscale had .80 , the negative had .82 , the retreat had .74 and the subordination had .73 correlation coefficient. The Cronbach's alpha in the present study was found to be .75 for the positive resolution style subscale, .80 for the negative resolution style subscale, .74 for retreat and .77 for the subordination subscale.

The Bem-Sex Role Inventory (29) measures feminine and masculine characteristics. Kavuncu adapted this scale to the Turkish (30). The scale is composed of 60 adjectives, 20 of these adjectives measure feminine characteristics, 20 of them mea- sure masculine characteristics and 20 of them measure the characteristics which belong neither to femininity nor masculinity. The questions are answered on a 7 point Likert rating scale. Median split was used to define the categories of femininity and masculinity. The test-retest reliability was .75 for femininity, .89 for masculinity and .87 for social desirability. The Cronbach's alpha in the present study for the femininity subscale was found to be .78 and .81 for the masculinity subscale.

\section{Procedure}

54 male and 69 female participated in the present study. They were selected by convenience sampling. In order to get the study participants different work places such as coiffeurs, airports, police offices, primary schools were visited and a brief information about the present study was given to the employees. Then the survey package was distributed as hard copy to the people who were willing to take a part in the study. The participants were asked to fill out and return survey package in a week. The survey package included the demographic information form, Marital Life Scale, Paulson Daily Living Inventory, Conflict Resolution Style Scale and Bem-Sex Role Inventory.

\section{RESULTS}

\section{Relationship among Projective Identification, Conflict Resolution Styles and Marital Satisfaction}

Pearson correlation analysis showed that there was a positive correlation between persecuting projective identification and negative conflict resolution style $(\mathrm{r}=.354, \mathrm{p}<.01)$. Persecuting projective identification was negatively correlated with positive conflict resolution styles $(\mathrm{r}=-.274, \mathrm{p}<.05)$. There was a positive correlation between idealizing projective identification and subordination behaviors $(\mathrm{r}=.436, \mathrm{p}<.01)$. Also, there was a positive correlation between idealizing projective identification and marital satisfaction $(\mathrm{r}=.534, \mathrm{p}<.01)$. However, persecuting projective identification and marital satisfaction were negatively correlated $(\mathrm{r}=-.574$, $\mathrm{p}<.01)$. There was a positive correlation between 
Table 2. Correlations among Projective Identification, Conflict Resolution Styles and Marital

\begin{tabular}{|c|c|c|c|c|c|c|c|}
\hline & 2 & 3 & 4 & 5 & 6 & 7 & 8 \\
\hline 1.idealizing projective identification & $-.189 *$ & .034 & .119 & -.110 & $.436 * *$ & .127 & $.534 * *$ \\
\hline 2.persecuting projective identification & & $-.250^{* *}$ & $-.274^{*}$ & $.354^{* *}$ & .118 & .150 & $-.574 * *$ \\
\hline 3.positive conflict resolution style & & & & $-.311^{* * *}$ & .137 & -.009 & $.269 * *$ \\
\hline 4.negative conflict resolution style & & & & & $-.243^{* *}$ & -.045 & $-.329 * *$ \\
\hline 5.subordination & & & & & & $.471^{* *}$ & .097 \\
\hline 6.retreat & & & & & & & -.123 \\
\hline 7.marital satisfaction & & & & & & & \\
\hline
\end{tabular}

positive conflict resolution style and marital satisfaction $(r=.269, \mathrm{p}<.01)$, whereas negative conflict resolution style and marital satisfaction were negatively correlated $(\mathrm{r}=-.329, \mathrm{p}<.01)$.

\section{The relationship among Socio-demographic Variables and Marital Satisfaction}

The relationship among socio-demographic variables and marital satisfaction were also examined by using t-test and correlational analysis. The results indicated a negative correlation between duration of marriage and marital satisfaction $(r=$ $.346, \mathrm{p}<.01)$. A significant difference was found between couples with a child and couples without a child $(\mathrm{t}(119)=2,304, \mathrm{p}<.05)$. Couples with a child have lower marital satisfaction scores than couples without a child. A negative correlation between the number of children and marital satisfaction $(\mathrm{r}=$ $.192, \mathrm{p}<.05)$ indicated that the more the children the lower the marital satisfaction. Lastly, a negative correlation between the frequency of conflict and marital satisfaction was found $(\mathrm{r}=-.506, \mathrm{p}<.01)$, suggesting that couples who do not resolve their conflicts have low level of marital satisfaction.

\section{Effects of Sex and Gender Roles on Conflict Resolution Styles, Marital Satisfaction and Projective Identification}

Gender roles were examined in two categories; having feminine and masculine personality characteristics. Having feminine and masculine personality characteristics have two levels; high and low, which were defined by median split. A series of 2X2X2 ANOVA were conducted to explore the effect of sex, feminine and masculine personality characteristics on marital satisfaction and conflict resolution styles

The significant results showed that there was a main effect of feminine personality characteristics on subordination behaviors $(F(1,115)=18.068$, $\left.\mathrm{p}<.01, \mathrm{np}^{2}=.136\right)$ and on negative conflict resolution styles $\left(\mathrm{F}(1,115)=4.630, \mathrm{p}<.05, \mathrm{np}^{2}=.039\right)$. There was a main effect of having feminine personality characteristics on negative resolution styles $\left(\mathrm{F}(1,115)=4,630, \mathrm{p}<.05, \mathrm{np}^{2}=.039\right)$. These results suggest that people with high level of feminine personality characteristics are more likely to engage subordination behaviors and negative resolution styles in a conflictual situation than people with low level of feminine personality characteristics. Further, the main effect of sex on subordination behaviors $\left(\mathrm{F}(1,115)=5,970, \mathrm{p}<.05, \mathrm{np}^{2}=.049\right)$ indicates that males were more likely to use subordination behaviors than females.

With regards to the marital satisfaction, only the feminine personality characteristics was found to have a significant effect on marital satisfaction ( $F$ $\left.(1,115)=4.059, \mathrm{p}<.05, \mathrm{np}^{2}=.034\right)$. People with high in feminine personality characteristics have higher marital satisfaction level than people with low in feminine personality characteristics. There was no significant interaction effect.

In terms of the projective identification, both the feminine and masculine characteristics were found to have a significant effect on idealizing projective identification $\left(\mathrm{F}(1,119)=5.919, \mathrm{p}<.05, \mathrm{np}^{2}=.047\right)$. The feminine characteristics has a significant effect on idealizing projective identification $(\mathrm{F}(1,119)=$ 14.812, $\left.\mathrm{p}<.01, \mathrm{np}^{2}=.11\right)$. These findings suggest that people with high feminine characteristics tend to use idealizing projective identification for 
people with high level of masculine characteristics.

\section{Predictors of Marital Satisfaction}

Multiple regression analysis indicated that the linear combinations of conflict resolution styles, gender roles and projective identification styles were significantly related to marital satisfaction, ( $F$ $(8,122)=17.65, p<.01)$. All of these variables can account for $52 \%$ of variance in marital satisfaction. Idealizing projective identification was positively related to marital satisfaction $($ Beta $=.49, \mathrm{t}[122]=$ 6. $47 ; \mathrm{p}<.001)$ whereas, persecuting projective identification was negatively related to marital satisfaction $($ Beta $=-.39, \mathrm{t}[122]=-5.35, \mathrm{p}<.001)$.

\section{DISCUSSION}

The present study aims to explore the relationship between projective identification gender roles, conflict resolution and marital satisfaction. The finding of this study showed that using persecuting projective identification was positively associated with negative conflict resolution styles and marital satisfaction, whereas idealizing projective identification was positively correlated with subordination and marital satisfaction. This study found the effect of feminine characteristics on subordination beha viors, negative resolution styles and marital satisfaction and the effect of both masculine and feminine characteristics on idealizing projective identification. Lastly, a negative correlation marital satisfaction with duration of marriage, the number of children, and unresolved conflict was found.

As discussed before projective identification is primarily an internal process explained by psychodynamic theory and denotes a primary defense mechanism associated with personality disorders. In projective identification the person attempts to induce in his or her partner the self-representation from the original negative interaction. Early identification processes with the parent has strong effect on partner's conflict resolution styles. Persecuting projective identification in couple relationships is a recurrent pattern of the couples' negative childhood experiences with parents such as abusive, instable and selfish parenting behavior. A person who experienced a conflicted relationship with parents, may split the ego into two parts. One part is related to being aggressive and rebellious, whereas the other part is related to being submissive and dependent. If the person projects his/her aggressive part, the receiver is perceived as mean and controlling. If the person is afraid of losing the love of the partner the person projects the dependent and submissive part, the receiver is perceived as gratifying and loving. People who use persecuting projective identification may act out their aggression whereas, people who use idealizing projective identification are more likely to turn aggression against the self $(6,31)$. The results of the present study also support these findings suggesting that using persecuting projective identification leads the couple to transfer their early childhood conflicts on each other which then results in marital distress. Because couple who use persecuting projective identification have poor communication skills, conflict resolutions, also show aggressive behaviors. On the other hand, the positive relationship between the idealizing projective identification and marital satisfaction suggest that couples attribute positive meaning to the relationship such as caring, supportive, and empathic.

The findings of this study also support the previous results indicating that feminine people are more likely to use internalizing defense mechanisms such as turning against self; whereas, masculine people use externalizing defense mechanisms such as displacement and aggressive forms of acting out $(32,33,34)$. In internalizing defenses, such as turning against self, aggression turns inward; whereas, in externalizing defenses, aggression projects outward. By using internalizing defenses, feminine people may repress and deny their anxiety or they may blame themselves for the unwanted content. However, in externalizing defenses people blame others for their anxiety and unwanted content. In negative resolution style resentment, hostility and rage are the feelings exchanged between partners. In this sense, externalizing defenses such as aggressive forms of acting out can be related to negative conflict resolution styles; whereas, internalizing defenses can be positively related to subordination behaviors and negatively associated with negative resolution behaviors. The interaction effect of masculine and feminine characteristics on idealizing projective identification suggest that both feminine 
characteristics such as being a caretaker and being sensitive to other's feelings and masculine characteristics such as acting like a leader and being dominant nurtures their relationship which in turn increases marital satisfaction $(10,35)$. The association of feminine characteristics with idealizing projective identification indicates full acceptance of a partner without questioning that may be the result of a gender expectancy. It may be concluded that in idealizing projective identification, a person may feel dependent on a partner, can be self-sacrificing and try to avoid any relational conflict.

The destructive outcomes of marital discord have been well documented, but studies of the underlying processes which contribute to marital satisfaction have not been clearly identified. The present study introduced the integrative perspective for marital satisfaction by examining different components of Turkish couple relationship. This study showed that some components in a couple interaction styles are the result of projective identifications, gender roles and conflict resolutions styles. There is the explication of conscious and unconscious processes within the couple relationship which forces the couple and the therapist to look beyond the instrumental features of marriage. The early relationship with the parents is a very crucial dynamic for future close relationships and therefore, emphasized the importance of an awareness of projective identification in working with couples. Understanding that destructive adult interaction styles which may be created during negative childhood interactions may help clinicians to create a more appropriate model in working with couples. Knowledge about inherent adult interaction styles might aid couples in acceptance of differences as well as assist in teaching moderation techniques for basic temperament styles. Also marital satisfaction increases when couple employs more effective conflict resolution skills. The use of psycho-educational techniques that should show couples how their communication patterns and problem solving styles interfere with their relationship and contribute to marital dissatisfaction will help couples to develop better problem management structure and resolution strategies.

In the first years of marriage, blind love may prevent people to see some facts about each other.
However, as the time pass by couples realize their differences with regards to finance, domestic chores, social circle and child raising. As stated Chapin, Chapin, and Sattler, conflicts over child rearing cause a great level of marital distress (36). Especially, the more couple argue the less they are satisfied with each other. The findings of this study are in line with the previous research findings suggesting that having children reduces marital satisfaction due to the lowering couples' interaction and increasing responsibilities $(28,37)$.

There are some limitations of the present study. Most of the participants come from high social economic status (SES) and high educational background. This sample may not represent the whole Turkish population. The design of the study was cross-sectional, therefore, it was impossible to examine longitudinal factors that affect couple relationships. Considering a strong association of projective identification with personality disorders, this study did not include the assessment of personality which may limit the findings.

Overall, couples today face unique challenges as they struggle to maintain the marital intimacy. The findings of this study will shed some light on the field of marriage and family therapy to ensure the effectiveness of interventions.

Address for correspondence: Doç. Dr. Ayten Zara, Istanbul Bilgi University; Psychology Department, Istanbul ayten.zara@bilgi.edu.tr 


\section{REFERENCES}

1. Abedi MR, Bahrami F, Etemadi O, Fatehizadeh M, Ghasemi V. Personality types and marital satisfaction. Interdiscip $\mathrm{J}$ Contemp Res in Bus 2012; 4:372-383.

2. Blum JS, Mehrabian A. Personality and temperament correlates of marital satisfaction. J Pers 1999; 67:93-125.

3. Chescheir MW. Projective processes as interpersonal communication. Smith Coll Stud Soc Work 1995; 66:17-37.

4. Dumitrescu D, Rusu AS. Relationship between early maladaptive schemas, couple satisfaction and individual mate value: An evolutionary psychological approach. J of Cogn Behav Psychother 2012; 12:63-76.

5. Gottman JM, Krokoff LJ. Marital interaction and satisfaction: A longitudinal view. J Consult Clin Psychol 1989; 57:47-52.

6. Siegel JP. Identification as a focal point in couple therapy. Psychoanal Inq 2004; 24:406-419.

7. Gabbard G. Psychodynamic Psychiatry in Clinical Practice. Edited by Gabbard G. Washington, DC, American Psychiatric Press, 2005. pp. 210-312.

8. Ogden TH. On projective identification. Intl J Psychoanal 1979; 60:357-373.

9. Mendelsohn R. The projective identifications of everyday life. Psychoanal Rev 2009; 96:871-893.

10. Göral-Alkan S. Coupling through projective identification: bridging role of projective identification in the associations among early parenting experience, personality constructs and couple relationship. M.E.T.U. Sosyal Bilimler Enstitüsü, Doktora Tezi 2010.

11. Kovacs GS. Impact of projective identification, shame proneness, level of empathy and self-esteem on couple relationship satisfaction. C.S.P.P. Doctoral Dissertation. 1996.

12. Solomon M, Siegel JP. Countertransference and Empathy in Couples Therapy. In: Countertransference in Couples Therapy. Edited by Solomon M, Siegel JP. New York, Norton, 1997, 89167.

13. Fincham FD. Marital conflict: Correlates, structure, and context. Curr Dir Psychol Sci 2003; 12:23-27.

14. Gottman J, Markman H, Notarius C. The topography of marital conflict: A sequential analysis of verbal and nonverbal behavior. J Marriage Fam 1977; 39:461-477.

15. Gottman J. The roles of conflict engagement, escalation, and avoidance in marital interaction: A longitudinal view of five types of couples. J Consult Clin Psychol 1993; 61:6-15.

16. Brehm SS. Intimate Relationships. Edited by Brehm SS. New York, McGraw- Hill, 1992, pp. 129-242.

17. Greeff AP, Bruyne T. Conflict management style and marital satisfaction. J Sex Marital Ther 2000; 26:321-334.

18. Heavey CL, Layne C, Christensen A. Gender and conflict structure in marital interaction: A replication and extension. $\mathbf{J}$ Consult Clin Psychol 1993; 61:16-27.

19. Straus MA. Measuring intrafamily conflict and violence: The conflict tactics (CT) scales. J Marriage Fam 1979; 41:85-88.
20. Amato PR, Loomis L, Booth A. Parental divorce, marital conflict, and offspring well-being during early adulthood. Soc Forces 1995; 73:895-915.

21. Bal H. Bağlanma stilleri, cinsiyet rolleri ve evlilik uyumu arasındaki ilişkinin incelenmesi. M.U. Sosyal Bilimler Enstitüsü, Master Tezi. 2007.

22. McGovern JM, Meyers SA. Relationships between sex-role attitudes, division of household task, and marital adjustment. Contemp Fam Ther 2002; 24:601-618.

23. Anar B. Evli ve çalışan yetişkinlikerin toplumsal cinsiyet rolleri ile evlilik doyumu ve iş doyumu ilişkisinin incelenmesi. Ç.U. Sosyal Bilimler Enstitüsü, Master Tezi. 2011.

24. Çınar L. Evlilik doyumu: cinsiyet rolleri ve yardım arama tutumu. G. U. Eğitim Blimleri Enstitüsü, Master Tezi. 2008.

25. Dasgupta S, Basu J. Marital quality and gender role stereotype. Psychol Stud 2011; 56:360-367.

26. Tezer E. Evli Eşler Arasındaki Çatışma Davranışları: Algılama ve Doyum. H.U. Sosyal Bilimler Enstitiüsü, Doktora Tezi.1986.

27. Paulson I. Projective identification in family interaction a methodological study. U.S.C., Humanities, Unpublished dissertation. 1978 .

28. Özen A. Value similarities of wives and husbands and conflict resolution styles of spouses as predictors of marital adjustment. M.E.T.U. Sosyal Bilimler Enstitüsü, Doktora Tezi. 2006.

29. Bem SL. The measurement of psychological androgyny. J Consult Clin Psychol 1974; 42:155-162.

30. Kavuncu AN. Bem Cinsiyet Rolü Envanterini Türk Toplumuna Uyarlama Çalısmaları. H.U. Sosyal Bilimler Enstitüsü, Master Tezi. 1987.

31. Chatao Y, Whisman MA. Partner schemas and relationship functioning: a states of mind analysis. Behav Ther, 2009; 40:5056.

32. Bogo N, Winget C, Gleser GC. Ego defenses and perceptual styles. Percept Mot Skills 1970; 30:599-605.

33. Cramer P. Children's use of defense mechanisms in reaction to displeasure caused by others. J Pers 1983; 51:79-94.

34. Cramer P. The development of defenses. J Pers 1987; 55:597612.

35. Stoller R. Sex and Gender: On the Development of Masculinity and Femininity. New York, Science House, 1968.

36. Chapin LR, Chapin TJ, Sattler LG. The relationship of conflict resolution styles and certain marital satisfaction factors to marital distress. Fam J 2001; 9:259-265.

37. Kurdek LA. The nature and predictors of the trajectory of change in marital quality for husbands and wives over the first 10 years of marriage. Dev Psychol 1999; 35:1283-1296. 